\title{
Gangrene or Cancer? Sixteenth-Century Medical Texts and the Decay of the Body of the Church in Jean Calvin's Exegesis of 2 Timothy 2:17
}

\author{
Lindsay J. STARKEY
}

Kent State University at Stark

In 2 Timothy 2:17, Paul compared the effects of false teachings on the Church to a disease. Rejecting previous translations that identified this disease as cancer, Jean Calvin (1509-64) insisted that it must be gangrene in his 1548 commentary on this epistle, citing and discussing medical texts to justify his translation. This article places his commentary in the context of these medical texts. The causes, courses, and treatments his contemporaries associated with gangrene provide insight into Calvin's idea of the people likely to spread false teachings and of how they should be treated: because, for him, the experience of gangrene reflected the real effects of false teachings on the Church. This manuscript argues that consulting other areas of sixteenth-century knowledge, such as medicine, was a part of Calvin's exegetical practice. It also suggests that modern scholars need to take these other areas of knowledge into account when analyzing sixteenth-century biblical commentaries.

Dans 2 Timothée 2:17, Paul compara les effets des faux enseignements sur l'Église à une maladie. Ayant rejeté les traductions précédentes qui identifiaient cette maladie comme cancer, Jean Calvin (1509-1564), dans son commentaire de cette épître en 1548, soutint qu'il devait s'agir de la gangrène et il justifia cette traduction en citant et discutant des sources médicales. Cet article situe ce commentaire dans le contexte de ces textes médicaux. Les causes, les symptômes et les traitements associés à la gangrène, portent un discours sur ceux qui, selon Calvin, propageraient les faux enseignements, ainsi que sur la façon dont on doit les traiter. Pour Calvin, en effet, la réalité de de la gangrène reflète, dans l'expérience, les effets des faux enseignements sur l'Église. Cette étude examine de la pratique exégétique de Calvin, qui consulte d'autres domaines de la connaissance, comme la médecine, pour lire les textes. Aussi il propose que les savants modernes doivent prendre en compte ces autres domaines pour analyser les commentaires bibliques $d u X V I^{e}$ siècle.

In addition, avoid empty and profane clamours for they will bring forth greater impiety. And their speech (sermo) will eat as gangrene. ${ }^{1}$

Jean Calvin's translation of 2 Timothy 2:16-17 (1548)

1. "Caeterum profanas clamorum inanitates omitte. Ad maiorem enim proficient impietatem: \& sermo eorum, ut gangraena pastionem habebit." Jean Calvin, Ioannis Calvini Commentarii in utranque Pauli epistolam ad Timotheum (Geneva: Jean Gerard, 1548), sig. g8v. Calvin edited his commentaries on the Pauline epistles and released collected volumes of them in 1551 and 1556 . He provided the same translation and explanation of this verse in these subsequent editions. 
$\mathrm{J}$ ean Calvin (1509-64) offered a translation of 2 Timothy 2:17 that differed from most biblical translations to date. Like other translators, he held the notion that profane and empty speech was dangerous for a religious community; like them, he compared such speech to a disease that would eat away at the Church's body. What stands apart in his translation is its identification of the disease. The Latin Vulgate had identified it as "cancer."2 Erasmus of Rotterdam (1466-1536) retained this same word in his Latin translation of the New Testament text in both the Novum Instrumentum (1516) and the Novum Testamentum (1519). ${ }^{3}$ The word "chancre" also appeared in Pierre Robert Olivétan's 1535 French translation of the biblical text. ${ }^{4}$ Yet, despite this previous translation history, Calvin identified this disease as gangrene.

His translation choice is even more surprising when we realize that Calvin likely knew all of these previous translations. The Vulgate was the biblical text from and against which Calvin and other religious reformers both drew and reacted. ${ }^{5}$ Olivétan (ca. 1506-38) was Calvin's cousin, and Calvin had actually

2. In the Latin Vulgate, 2 Timothy 2:15-18 reads, "sollicite cura te ipsum probabilem exhibere Deo operarium inconfusibilem recte tractantem verbum veritatis profana autem inaniloquia devita multum enim proficient ad impietatem et sermo eorum ut cancer serpit ex quibus est Hymeneus et Philetus qui a veritate exciderunt dicentes resurrectionem iam factam et subvertunt quorundam fidem."

3. "Stude teipsum probatum exhibere deo, operarium non erubescentem, recte secantem verbum veritatis caeterum prophanas vocum inanitates praetermittito. Ad maiorem enim proficient impietatem, \& sermo illorum ut cancer morbus serpet. Quorum de numero est Hymenaeus \& Philetus qui circa veritatem aberraverunt, dicentes resurrectionem iam esse factam, \& subvertunt quorundam fidem." Erasmus of Rotterdam, Novum Instrumentum omne (Basel: Johann Froben, 1516), sig. I3r. "Stude teipsum probatum exhibere deo, operarium non erubescendum, recte secantem sermonem veritatis. Caeterum prophanas vocum inanitates praetermittito. Ad maiorem enim proficient impietatem, \& sermo illorum ut cancer morbus, pastionem habebit, quorum de numero est Hymenaeus \& Philetus qui circa veritatem aberraverunt, dicentes resurrectionem iam esse factam, \& subvertunt quorundam fidem." Erasmus of Rotterdam, Novum Testamentum omne (Basel: Johann Froben, 1519), sig. Q3r.

4. "Faits diligence de presenter soymesme approuve a Dieu ouvrier dusques on nayt point honte bien tracitant sa parolle de verite. Aussi defaisse les vanites de propos prophanes. Car ils auanceront a plusgrande meschancete. Et la parolle diceusy comme chancre aura pasture desquafs est Hymenne et Philete qui se sont defuoyes de sa verite disans: que la resurrection est desia faicte a subvertissent sa foy daucuns." Pierre Robert Olivétan, La Bible qui est toute la saincte escripture (Neuchâtel: Pierre de Vingle, 1535), sig. ffiiiiv.

5. For Calvin's use of the Vulgate in his New Testament commentaries, see T. H. L. Parker, Calvin's New Testament Commentaries (Grand Rapids, MI: William B. Eerdmans, 1971), 142-46. 
written a Latin preface for his French-language Bible. ${ }^{6}$ Calvin also stated in his commentary on 2 Timothy 2:17 that Erasmus had erred by conflating gangrene with cancer in his translation of the verse. ${ }^{7}$ My article explores the reasons why Calvin insisted that the disease must be gangrene, despite a thousand years of translation history that held otherwise. As he commented on this verse, Calvin explicitly drew on contemporary medical knowledge to show that gangrene was a more appropriate vehicle of Paul's metaphor than cancer. In other words, Calvin did draw on information in the liberal sciences, such as medicine, when he interpreted Paul's epistles-much as Randall C. Zachman has argued for Calvin's exegesis of the Hebrew Scriptures. ${ }^{8}$ Exploring this intersection of exegesis and medicine in his commentary not only provides insight into Calvin's exegetical method, however'; it also sheds light on sixteenth-century biblical commentary more broadly. Contemporary medical discourses provide crucial contexts for understanding these commentaries.

For Calvin, the effect of false teachings on religious communities as referenced in 2 Timothy 2:17 was of the utmost importance. For much of his life, Calvin repeatedly interacted and argued with those who had other interpretations of Christian doctrine. In 1538, Calvin had been exiled from the city of Geneva for his views on the relative authority of magistrates and ministers. Moving to Strasbourg, he also interacted with and confronted those who held opposing notions of Christian doctrine. ${ }^{10} \mathrm{He}$ first began his commentary on Paul's epistles while in Strasbourg as a way to investigate this doctrine in detail. He continued the project when he returned to Geneva in 1541-a project that

\section{Olivétan, sig. *iiv.}

7. Calvin, Commentarii in utranque Pauli epistolam ad Timotheum, sig. h1v.

8. Randall C. Zachman, “Gathering Meaning from the Context: Calvin's Exegetical Method," in John Calvin as Teacher, Pastor, and Theologian: The Shape of His Writings and Thought (Grand Rapids, MI: Baker Academic, 2006), 122-25.

9. On the distinction between exegetical practices and hermeneutical principles in Calvin's commentaries on the Pauline epistles, see R. Ward Holder, John Calvin and the Grounding of Interpretation: Calvin's First Commentaries (Leiden: Brill, 2006).

10. William G. Naphy, Calvin and the Consolidation of the Genevan Reformation, 2nd ed. (Louisville: Westminster John Knox Press, 2003). See also, E. William Monter, Calvin's Geneva (New York: Wiley, 1967). 
he did not finish until 1551. ${ }^{11}$ Exploring the disease of 2 Timothy 2:17 and its implications for a Christian religious community therefore allowed Calvin to think through a basic question about his role as a religious reformer: how a minister could protect the members of his community from those teachings he deemed false.

Scholars such as T. H. L. Parker have argued that Calvin's translation of and commentary on this particular verse reflect his knowledge of Greek and his interest in reading sources in their original languages. ${ }^{12}$ Parker explains that Calvin took great trouble to establish the biblical text in his commentaries because Calvin believed that the role of the expositor was to lay bare the meaning of the text as clearly and concisely as possible. Assuming that the text faithfully communicated the message God wanted people to receive, it was crucial that the expositor know the actual words of this message..$^{13}$ There is evidence in Calvin's commentary on 2 Timothy 2:17 that the Greek original affected his exegesis. He notes that some people might have mistaken the disease for cancer if they worked solely in Latin because the Latin word "cancer" was often used for a wide variety of diseases, including gangrene. If one worked in Greek, however, he argues that the words for cancer and gangrene were quite distinct, and he claims that Paul had actually used the Greek word for gangrene in his epistle. $\mathrm{He}$ also provides the etymology for "gangrene," claiming that it came from the Greek verb for "to devour." ${ }^{14}$

Though the Greek text of 2 Timothy certainly influenced Calvin's translation of verse 17 , if we attend to the rest of his commentary we find that the original language of the text was not the only determining factor for his translation and understanding. The actual courses of these two diseases-how his contemporaries thought cancer and gangrene affected a human body-also

11. On Calvin's commentaries on the Pauline epistles more generally, see R. Ward Holder, "Calvin as Commentator on the Pauline Epistles," in Calvin and the Bible, ed. Donald K. McKim (Cambridge: Cambridge University Press, 2006), 224-56.

12. Parker claims that Calvin here corrected what he saw as Erasmus's mistranslation of Paul. He describes the passage thus: "A remarkable passage! Two hundred and fifty words of Latin just to explain

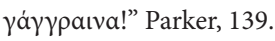

13. Parker, 49-68.

14. Calvin, Commentarii in utranque Pauli epistolam ad Timotheum, sigs. h1v-h2r. Erasmus's Novum Instrumentum and Novum Testamentum might have convinced Calvin of Paul's use of this Greek word,

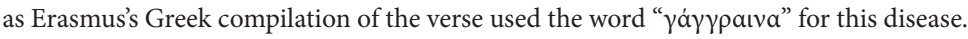


shaped his translation and analysis. Commenting on a verse that described the ways in which false teachings would damage a Christian religious community, Calvin assumes that Paul's use of metaphor taught Christians something true about the impact of these profane and empty clamours. ${ }^{15}$ His commentary shows that it was necessary to understand the actual courses of gangrene and cancer in order to grasp Paul's point about the effects these false teachings had on these communities. Thus, to describe the two diseases, Calvin explicitly discusses medical and surgical texts as well as information he had received from a contemporary doctor, Benedict Textor (ca. 1509-60).

Sixteenth-century medical and surgical texts are therefore crucial background for understanding Calvin's translation of and commentary on 2 Timothy 2:17. As Alexandra Walsham has argued, the realms of religion and medicine overlapped in early modern Europe as Christians of all confessions held that both the condition of the soul and the condition of the body affected human health. ${ }^{16}$ Michael Stolberg has also recently noted that historians working with nonmedical texts "may easily miss the specific meanings and connotations of medical metaphors in their sources [...] if they do not pay sufficient attention to the specific literal meaning of these terms in contemporary medicine." ${ }^{17} \mathrm{My}$ article will therefore begin with an investigation of the medical sources that Calvin specifically names in his commentary as well as of those on which he likely drew. This discussion will provide the crucial background through which we can interpret Calvin's commentary on the verse. Though the metaphorical vehicle of either cancer or gangrene would suggest that false teachings endanger the body of the Church, knowing the particular causes and treatments Calvin's

15. Calvin describes Paul's comparison of gangrene and its effect on the human body to the effect of false teachings on religious communities thus: "[...] eleganter cum tam exitiali contagione Paulus adulterinas doctrinas comparat." Calvin, Commentarii in utranque Pauli epistolam ad Timotheum, sig. h2r. For a discussion of how Calvin viewed biblical metaphors, see Olivier Millet, Calvin et la dynamique de la parole: étude de rhétorique reformée (Paris: Librairie Honoré Campion, 1992), 297.

16. Alexandra Walsham, "In Sickness and Health: Medicine and Inter-Confessional Relationships in Post-Reformation England," in Living with Religious Diversity in Early Modern Europe, ed. C. Scott Dixon, Dagmar Friest, and Mark Greengrass (Aldershot: Ashgate, 2009), 161-81. See also David N. Harley, "Medical Metaphors in English Moral Theology, 1560-1660," The Journal of the History of Medicine and Allied Sciences 48 (1993): 396-435.

17. Michael Stolberg, "Metaphors and Images of Cancer in Early Modern Europe," Bulletin of the History of Medicine 88.1 (2014): 7. Stolberg builds on the insights Susan Sontag expressed in her Illness as Metaphor (New York: Farrar, Straus, \& Giroux, 1978). 
contemporaries assigned to these diseases will shed light on his understanding of who would most likely cause problems in religious communities, and how such people should be treated so that the community might escape peril. His usage of these medical and surgical texts shows that Calvin drew on other sixteenth-century areas of knowledge in order both to understand biblical verses and to convey his understanding in a culture where the experiences of cancer and gangrene as well as their treatments were familiar enough to his audience. ${ }^{18}$ The example of Calvin's usage of medical texts to elucidate 2 Timothy 2:17 also suggests that we cannot read biblical commentators only in the context of other biblical commentaries. The wider scope of sixteenth-century knowledge must be taken into account whenever we attempt to understand biblical exegesis.

\section{Gangrene and cancer in sixteenth-century medical and surgical texts}

Calvin credits his doctor, Textor, with the initial information about gangrene's difference from cancer in the first line of his commentary, revealing that Textor helped shape Calvin's views of these two diseases. ${ }^{19}$ Born in the town of Pont de Vaux in France, Textor was educated in Paris and also attended medical lectures at the Collège Royal. Though it is possible that Textor met Calvin while they were both in Paris, as their studies did overlap there in the 1530s, there is no record of such a meeting. After finishing his medical education, Textor moved to Macon, but he travelled extensively throughout France and in French-speaking Switzerland, living at various times in Macon, Neuchâtel, Lausanne, and Geneva. At some point in the 1540s, Textor became the personal physician to Calvin and his wife, Idelette de Bure. ${ }^{20}$ Calvin appears to have valued Textor's medical

18. Christopher B. Kaiser has argued something similar for Calvin's understanding and usage of Aristotelian natural philosophy in his attempt to reform the Church. See his "Calvin's Understanding of Aristotelian Natural Philosophy: Its Extent and Possible Origins," in Calvin and Science, ed. Richard C. Gamble (New York: Garland Publishing, Inc., 1992), 143-58. On Calvin's education and his extensive knowledge base, see Abel Lefranc, La jeunesse de Calvin (Paris: Librairie Fischbacher, 1888); Quirinus Breen, John Calvin: A Study in French Humanism, 2nd ed. (Hamden, CT: Archon Books, 1968); Alexandre Ganoczky, The Young Calvin, trans. David Foxgrover and Wade Provo (Philadelphia: Westminster Press, 1987); and William J. Bouwsma, John Calvin: A Sixteenth-Century Portrait (New York: Oxford University Press, 1988).

19. Calvin, Commentarii in utranque Pauli epistolam ad Timotheum, sig. h1v.

20. On Textor's relationship with Calvin, see Machiel A. van den Berg, Friends of Calvin, trans. Reinder Bruinsma (Grand Rapids, MI: William B. Eerdmans, 2009), 134-43. 
expertise very highly as he dedicates his commentary on 2 Thessalonians (1551) to Textor, thanking him for his treatment of Calvin as well as his wife, who had died in March 1549. ${ }^{21}$

Cancer was a topic with which Textor was especially concerned. In 1550, just two years after Calvin's commentary on 2 Timothy had appeared, Textor published a text on the nature and treatment of cancer. ${ }^{22}$ Though we cannot know whether Textor discussed this work with Calvin, if we compare the medical sources Textor cites with those Calvin discusses in his commentary, we find that Textor's and Calvin's sources coincide. Textor begins his text with citations of Galen's second-century De tumoribus praeter naturam and the sixth book of the seventh-century Byzantine physician Paul of Aegineta's medical compendium. ${ }^{23}$ Just two pages later, he then cites the sixteenth book of fifth- and sixth-century Byzantine physician Aetius of Amida's Sixteen Books on Medicine. ${ }^{24}$ Calvin references all three of these authors and their works in his commentary to support his argument that the disease of 2 Timothy 2:17 must be gangrene, and he uses them to argue against a first-century Roman encyclopaedist, Cornelius Celsius, who, Calvin claims, had conflated the two diseases. ${ }^{25}$ Textor not only helped shape Calvin's view of gangrene and cancer, but their overlapping sources suggest that Textor might have pointed Calvin toward particular medical authorities for his information.

The emphasis on anatomy and surgical knowledge in sixteenth-century France also likely influenced Textor's understanding of gangrene and cancer and, by extension, his discussion with Calvin of the details that appeared in his commentary on 2 Timothy. Traditionally, the training to become a physician and the training to become a surgeon were different. Whereas becoming a physician typically required a university education, surgeons tended to belong

21. Jean Calvin, In omnes Pauli Apostoli Epistolas, atque etiam in Epistolam ad Hebraeos, item in Canonicas Petri, Iohannis, Iacobi, \& Iudae quae etiam Catholicae vocantur (Geneva: Robert Estienne, 1556), sig. Mvir.

22. Benedict Textor, De la nature \& cure du chancre, selon les meilleurs autheurs tant Grecs que Latins, par Benoit Textor Medecin (Lyon: Jean de Tournes, 1550).

23. Textor, De la nature \& cure du chancre, sig. A3v.

24. Textor, De la nature \& cure du chancre, sig. A4v.

25. Calvin, Commentarii in utranque Pauli epistolam ad Timotheum, sigs. h1v-h2r. 
to guilds, and these guilds set the educational requirements for their members. ${ }^{26}$ From 1506, however, medical students at Paris attended surgical lectures, and regular anatomy courses began to be offered there from the second quarter of the century. ${ }^{27}$ Vivian Nutton has argued that this introduction of surgical subjects into the medical curriculum in France and in other parts of Europe was likely due to the humanist emphasis on exploring ancient texts. She points out that the surgical works of influential ancient medical authors such as Galen, Paul of Aegineta, and Aetius were printed in Latin and/or Greek editions between the 1490s and the 1540s. She claims that this interest in ancient surgical texts perhaps had the biggest impact on France where twenty works on surgery appeared between 1537 and 1546, many of which were written in the vernacular. ${ }^{28}$ This milieu, in which surgery and anatomy as well as vernacular publishing on these subjects became more common, influenced both Textor's training as a physician and his publications of medical texts. In addition to studying at Paris after these surgical and anatomical lectures had been introduced, he also attended the anatomy lectures of Jacques Sylvius (1478-1555), one of the teachers of Andreas Vesalius (1514-64), at the Collège Royal. ${ }^{29}$ His choice to publish his work on cancer in French suggests the influence of this milieu. Many of his university-trained colleagues wrote French-language surgical texts and translated the surgical works of Galen, Paul of Aegineta, and Aetius into French in the 1530s and 1540s.

Textor's work on cancer and the translations of ancient surgical texts done in France prior to Calvin's commentary on 2 Timothy all show that sixteenth-century medical translators and writers made distinctions between gangrene and cancer. Though the courses of treatment were similar, these diseases were thought to have different causes and likely outcomes. These differences

26. Mary Lindemann, Medicine and Society in Early Modern Europe, 2nd ed. (Cambridge: Cambridge University Press, 2010).

27. Laurence Brockliss and Colin Jones, The Medical World of Early Modern France (Oxford: Clarendon Press, 1997), 90-107; Ernest Gurlt, Geschichte der Chirugie und ihrer Ausübung: VolkschirurgieAlterthum-Mittelalter-Renaissance, 2 vols. (Berlin: August Hirschwald, 1898), 2:1-121 and 2:606-924.

28. Vivian Nutton, "Humanist Surgery," in The Medical Renaissance of the Sixteenth-Century, ed. A. Wear, R. L. French, and I. M. Lonie (Cambridge: Cambridge University Press, 1985), 75-99.

29. Van den Berg, 136. Textor describes his own education in the letter to the reader of his Stirpium differentiae ex Dioscoride secundum locos communes: opus ad ipsarum plantarum cognitionem admodum conducibile (Paris: Simon Colinaeus, 1534), sigs. aiir-aiiiv. 
help us begin to understand Calvin's commentary more fully. Drawing on the work of Galen, sixteenth-century French medical authors argued that both diseases were a type of unnatural swelling or tumour, caused by the overabundance of one particular, corrupted humour. ${ }^{30}$ Jean Tagaut (d. 1546), professor of medicine at Paris and one of the teachers as well as the landlord of Textor, includes a lengthy description of these unnatural swellings in his 1543 work, De chirurgica. ${ }^{31}$ According to Tagaut, blood that had been inflamed and corrupted from its proper substance caused gangrene wherever it began to accumulate in the body. ${ }^{32}$ Swelling, caused by the accumulation of corrupt blood, blocked the circulation of vital spirit from the heart to the afflicted part of the body. With the vital spirit cut off, the gangrene threatened to spread into neighbouring flesh and bone. ${ }^{33}$ Tagaut also lists the signs by which people could recognize gangrene as opposed to another swelling. He explains that there was usually a florid colour near the inflammation and that the pain as well as the patient's pulse in the afflicted part of the body would lessen. Due to the lack of vital spirit, the body part would soon turn black and soft, and the swelling would rot and admit a terrible smell so that the body part had the appearance of a corpse. ${ }^{34}$

Though Tagaut argues that cancer is also a very serious disease, he explains that it had a different cause as well as different symptoms. He claims that the accumulation of black bile or the melancholy humour caused cancerous tumours that could either appear on the skin or be concealed within the body. ${ }^{35}$ He equates the visible form of this disease specifically with female breast and

30. Galen, Des Tumeurs oultre le coustumier de Nature, trans. Pierre Tolet (Lyon: Estienne Dolet, 1542), sigs. A2r-A3r.

31. This Jean Tagaut was the father of the Jean Tagaut who later made his way to Geneva and became the first professor of philosophy at the Geneva Academy. On the Geneva Academy, see Karin Maag, Seminary or University? The Geneva Academy and Reformed Higher Education, 1560-1620 (Aldershot: Scolar Press, 1995).

32. Jean Tagaut, Ioannis Tagaultii Ambiani Vimaci, Parisiensis medici, De chirurgica instititione libri quinque (Paris: Christian Wechelus, 1543), sig., ciiiir. Tagaut and the other authors also taught that gangrene could develop in surrounding wounds when these wounds blocked heat and vital spirit from reaching a particular part of the body.

33. Tagaut, sig. dviv.

34. Tagaut, sig. eir.

35. Tagaut, sig. kiiir. Textor made a similar claim in his De la nature \& cure du chancre on sig. A4r. 
uterine cancer due to women's tendency to retain menstrual blood. ${ }^{36}$ Tagaut explains the signs of the visible form of this disease, and his description resonates with those Paul of Aegineta and (later) Textor. For Tagaut, a visible cancerous tumour was a hard, unequal swelling, whose colour ranged between red and black, that sometimes caused pain and sometimes did not. He also comments on the veins that could grow around cancerous tumours, noting that they looked like crabs' legs. ${ }^{37}$ Whereas Textor's description of these tumours largely agrees with Tagaut's, ${ }^{38}$ Paul of Aegineta had claimed that these tumours were usually leaden coloured and that they did not cause pain. ${ }^{39}$

Despite the different causes and symptoms of cancer and gangrene, Galen, Paul of Aegineta, Tagaut, and Textor all argued that these diseases should be treated in a similar manner. Assuming you could not stop the accumulation of the corrupted humour in the first place, the main goal of the treatment was to break up this accumulation. These authors tended to stress that the doctor or surgeon had to act quickly in order to do so, due to the serious nature of these diseases. Their texts give a long list of unguents a healer could concoct and apply to the swellings to encourage the breaking up of the humoral accumulation. Most of their texts also advocate bloodletting, though they give different recommendations for the proper amount, time, and place. If these less intrusive techniques did not work, then one could take a more surgical approach to the case. The technique of scarification was one option-the process of making shallow cuts in the skin in the hope of excising smaller pieces of the accumulation. If scarification did not work, one could try to cut out the tumour, though there were a number of disagreements about this technique. In the case of cancer, likely due to the veins that surrounded cancerous tumours, a surgeon had to be very careful to get the roots of the accumulation, which were thought to be deep inside the patient's body. In the case of gangrene, there was disagreement over whether one should cut out only the afflicted tissue and then cauterize the surrounding flesh with boiling oil and hot iron tools or

36. Tagaut, sigs. Kiiir-Kiiiv. Paul of Aegineta had made a similar claim. See Paul of Aegineta, $L a$ Chirurgie de Paulus Aegineta, qui est le sixiesme Livre de ses Oeuures, trans. Pierre Tolet (Lyon: Estienne Dolet, 1540), sigs. Kiiiv-Kiiiiv.

37. Tagaut, sig. kiiiv. Ancient authors had named this disease "cancer" because of the veins' similarity to crabs' legs.

38. Textor, De la nature \& cure du chancre, sig. A3v.

39. Paul of Aegineta, sig. Kiiiv. 
whether one should also cut out some of the healthy flesh and cauterize around it to make sure one got all of the gangrenous inflammation. Amputation was a treatment of last resort in both cases because the process itself often killed the patient. ${ }^{40}$

The sixteenth-century treatments for gangrene and cancer might have been similar, but the ultimate outcomes of these diseases were understood to be very different. Tagaut and Textor, as well as the ancient authors on whom they drew, claimed that both were very serious diseases. For them, though, cancer was nearly always fatal, as Textor points out when he notes that all cancer was quasi incurable or at least very difficult to treat due to its tendency to ulcerate and spread..$^{41}$ Unlike the almost always fatal results of cancer, however, either gangrene was cured or it changed into a different disease and ceased to be gangrene. As Tagaut explains, gangrene, unless treated quickly, would turn into a disease, which in Latin was known as syderatio, in Greek as sphacelus, and more commonly as St. Anthony's fire. A body part afflicted with syderatio had lost all life, sense, and motion due to the lack of heat and vital spirit. This disease threatened to spread quickly to other parts of the body, often resulting in the patient's death. ${ }^{42}$ Whereas cancer killed, gangrene began to devour the body until either it was stopped or it changed into another disease that eventually sapped the body of all of its vital spirit. Assuming that the actual courses of these diseases taught people about the real impacts of false teachings on a Christian religious community, Calvin drew on medical texts to describe both gangrene and cancer in his commentary on 2 Timothy 2:17.

\section{Gangrene and cancer in Calvin's commentary on 2 Timothy 2:17}

That medical information could influence Calvin's biblical commentary should not surprise us. He wrote about the usefulness of medicine as early as the 1539

40. For the treatment of gangrene see Galen, sig. A8r and Tagaut, sigs. eiiv-eiiir. For the treatment of cancer, see Galen, sig. A8v, Paul of Aegineta, sigs. Kiiiv-Kvr, Tagaut, sigs. kiiiv-kviv, Textor, De la nature \& cure du chancre, sigs. A6r-D3r.

41. "Tout chancre est quasi incurable ou tres difficile à guerir veu que de tous son genre cest une tresmauuaise maladie, cest une ladrerie patriculiere." Textor, De la nature \& cure du chancre, sig. A6r.

42. Tagaut, sigs. dviv-eir. 
edition of the Institutio Christianae religionis ${ }^{43} \mathrm{He}$ also retained this discussion of medicine in the 1543 edition. Explaining how people should be able to discern God's revelation in the world, in the first chapter of the 1543 edition, he notes that medicine, especially if one had similar knowledge to Galen's, should allow one to perceive that God designed the human body-due to its symmetry, beauty, and the connections among its various parts. ${ }^{44}$ Calvin's description of the usefulness of medical knowledge, as well his relationship with Textor and, by extension, the entire context of French medical and surgical study in the 1530s and 1540s, appears explicitly in Calvin's commentary on 2 Timothy 2:17.

Much as contemporary medical authorities had, Calvin distinguishes between the diseases of cancer and gangrene on the basis of their causes, symptoms, courses, and outcomes in his commentary. He quotes Paul of Aegineta's definition of cancer to describe this disease's symptoms: "it is an unnatural swelling with swollen edges, foul to behold, greyish blue in color and without pain." ${ }^{45}$ Calvin also explains that medical writers typically identified two types of cancer, while giving its cause. The first type was hidden within the body and without ulcers. The second type was visible due to ulcers on the skin, which developed through the abundance of black bile. ${ }^{46}$ Turning to gangrene, Calvin discusses not its cause but rather its symptoms. Drawing on Galen, Aetius, and Paul of Aegineta, he argues that gangrene came from inflammations that could affect neighbouring parts of the body. If the inflammations made their way into a specific body part, they would cut off heat and the vital spirit to the extent that the body part was in danger of being destroyed. ${ }^{47}$

After stating yet again that cancer and gangrene are not the same disease and that the disease of 2 Timothy 2:17 is gangrene, he then turns to the course and outcomes of it. He explains that gangrene could change into another disease, depending on how it afflicted the body. If the body part should

43. On the importance of the 1539 Institutes for understanding Calvin's thought, see Richard A. Muller, The Unaccommodated Calvin: Studies in the Foundation of a Theological Tradition (New York: Oxford University Press, 2000).

44. Jean Calvin, Institutio Christianae Religionis (Strasbourg: Wendelinus Rihelius, 1543), sigs. A3r-v.

45. "Et Paulus Aegineta, ex illius authoritate, libro sexto cancrum ita definit: tumorem esse inaequalem, oris tumidis, aspectu tetrum, lividum, \& absque dolore." Calvin, Commentarii in utranque Pauli epistolam ad Timotheum, sig. h1v. See also Paul of Aegineta, sig. Kiiiv.

46. Calvin, Commentarii in utranque Pauli epistolam ad Timotheum, sig. h1v.

47. Calvin, Commentarii in utranque Pauli epistolam ad Timotheum, sig. h1v. 
become thoroughly dead due to the lack of heat and vital spirit, then a person no longer suffered from gangrene. Instead, the person had what was called in Greek, sphacelon, in Latin, syderatio, and more commonly, St. Anthony's fire. Once gangrene had reached this stage of mortification, the outcome was almost certainly fatal for the patient. The disease would eat into neighbouring body parts, penetrating to the bone. It would not stop its destruction until it killed the entire person. ${ }^{48}$

Comparing Calvin's descriptions of cancer and gangrene to those appearing in contemporary medical texts and contemporary translations of ancient medical works reveals a strong resonance between the texts. Calvin and the medical writers all argued that an overabundance of black bile was responsible for causing cancer, especially in its visible, ulcerous type. These authors also all taught that gangrene could easily spread into other parts of the body, due to its ability to cut off heat and vital spirit from particular body parts. Unlike the medical authors, Calvin does not discuss the outcomes of cancer; he had rejected this disease as the vehicle of Paul's metaphor in 2 Timothy $2: 17$. Instead, he focuses on the likely outcomes of gangrene as a way to explain Paul's meaning. Like contemporary medical authors, he explains that gangrene could actually turn into a different disease that was much more serious than the original gangrene. As the body part started to die off, gangrene changed into a disease, known commonly as St. Anthony's fire. It was the disease that gangrene became and not gangrene itself that would ultimately kill the afflicted. Clearly, contemporary medical knowledge shaped Calvin's commentary just as his insistence on reading the biblical text in the Greek original had. Calvin used the differences between cancer and gangrene to comment implicitly on which people were most likely to cause problems in a religious community and on how such false teachings should be treated so that they ceased to threaten the body of the Church.

\section{"And their speech will eat as gangrene"}

Calvin assumed that Paul had consciously compared gangrene to the effects of false teachings on Christian religious communities. For Calvin, gangrene's supposed cause and treatments, as discussed in contemporary medical texts, 
became a model through which he could explain how such false teachings arose and how to extract them. ${ }^{49}$ To understand fully the ways in which contemporary medical texts shed light on Calvin's commentary on 2 Timothy 2:17, we need to turn to another metaphor that was implicit in Calvin's explanation of this verse: the notion of the body of the Church. When we understand Calvin's notion of individual people, who joined together to form the single unit of a religious community much like individual body parts came together to form a single, functioning human body, we will see that Calvin thought men with sanguine temperaments were most likely to cause problems in such communities and that these men, if left to spread their false teachings, would persuade other individuals of these false doctrines unless they were thrown out of the communityeither exiled or burned for heresy.

Though its meaning was not agreed upon prior to the sixteenth century, religious reformations sparked many discussions and debates about the "body of the Church" metaphor. Sixteenth-century authors discussed and debated who was included in this body and how someone was incorporated into it. ${ }^{50}$ Calvin was therefore one sixteenth-century voice among many that addressed the meaning of this metaphor. He does so explicitly in his exegesis of Romans 12:4 and 1 Corinthians 12:12-27. ${ }^{51}$ Calvin's commentary on Romans first appeared in 1540, and his commentary on 1 Corinthians in 1546-eight and two years before his commentary on 2 Timothy. His commentary on these verses provides insight into his notion of the religious community, which the disease of the false teachings of 2 Timothy 2:17 could infect. In his commentaries on both biblical texts, Calvin takes the likening of the human body to the Church as unproblematic. ${ }^{52}$ He states in his commentary on 1 Corinthians 12:12 that the

49. On a similar use of metaphors of diseases among twelfth-century Christians, see R. I. Moore, "Heresy as Disease," in The Concept of Heresy in the Middle Ages ( $11^{\text {th }}-13^{\text {th }}$ C.), ed. W. Lourdaux and D. Verhelst (The Hague: Martinus Nijhoff, 1976), 9.

50. For Calvin and Geneva, see Karen E. Spierling, Infant Baptism in Reformation Geneva: The Shaping of a Community, 1536-1564 (Louisville, KY: Westminster John Knox Press, 2009), especially chapter 2, $31-60$.

51. Calvin also added a great deal of material on the Church to his 1543 edition of the Institutio Christianae religionis that had not appeared in the 1539 edition. This addition, along with his commentaries on Romans and 1 Corinthians, suggests that he was thinking through his understanding of the Church throughout the 1540s. See Calvin, Institutio Christianae religionis, sigs. Nviv-Vvv.

52. In his explanation of Romans 12:4-5, he simply states that just as there is a connection among the parts of the human body, Christ has instituted a connection among the faithful. Calvin, Commentarii in Epistolam 
human body was often used as a metaphorical vehicle for individuals who had been joined together into a single group. He cites Menenius Agrippa (d. 493 BCE), who had compared the patricians and plebeians of ancient Rome to a human body in order to reconcile the plebeians with the Senate into a single Roman Republic, as an ancient example of the metaphor Paul here invoked. ${ }^{53}$ For Calvin, however, the civic body Menenius Agrippa discussed was different than the spiritual and mystical body of Christ Paul wrote about in Romans 12:4 and 1 Corinthians 12:12-27. Whereas the ancient Roman Senate and the plebeians had shared a political polity, members of the Christian Church had been grafted onto Christ's body during baptism through the work of the Holy Spirit. Calvin is also careful to point out that this body of the Church did not include all the individuals in a contemporary, earthly religious community. The Holy Spirit's work was only efficacious for believers. Believers were incorporated into Christ's body and were actual members of the Church. Non-believers may be members of the current religious community, but they did not ultimately belong to the body of the Church, as they did not share its spiritual and mystical bond. ${ }^{54}$

Despite all being a part of this spiritual and mystical community, members of the Church were not all equal in the tasks that they performed for this body. As Calvin points out in both his Romans and 1 Corinthians commentaries, Paul's discussion assumes that each member of the body of Christ had a specific gift that allowed him or her to contribute to the Church in a certain manner. Though it was true that some of these gifts were more honourable than others, those with more menial gifts should not look with envy at those with more honourable ones. Those with honourable gifts should also avoid treating those with more menial ones with contempt. For Calvin, God had specifically arranged matters in this way so that all the tasks the Church needed would be accomplished by its members through the gifts God had bestowed on them. He also claimed that God had implanted people with an inclination to work toward the common good in order to make it more likely that all the necessary work would be accomplished and that the Church

\footnotetext{
Pauli ad Romanos, sig. Y2v.

53. Calvin, Commentarii in priorem espitolam Pauli ad Corinthios, sig. Biiiiv.

54. Calvin, Commentarii in priorem espitolam Pauli ad Corinthios, sigs. Bvr-Bvv. On Calvin's notion of believers and faith, see Barbara Pitkin, What Pure Eyes Could See: Calvin's Doctrine of Faith in Its Exegetical Context (New York: Oxford University Press, 1999).
} 
would survive, avoiding the schism of its members. ${ }^{55}$ For Calvin, then, inequality reigned among the individual members of contemporary Christian religious communities. There was a split between individual non-believers and those believers who were truly members of the body of Christ or the true Church. There was also a hierarchical division among believers within this body as each had a specific task to fulfill in order for the body of the Church to thrive.

According to Calvin, God knew which individuals were truly part of this body and which were actually the non-believers. People could not be certain who belonged to which category, and therefore, a contemporary religious community such as the one Calvin served in Geneva included both believers and non-believers. Returning to his commentary on 2 Timothy 2:17, and placing it in context with the medical texts on which Calvin drew to explain this verse, provides insight into Calvin's notion of who would most likely try to spread false teachings in such a community. In rejecting cancer as the vehicle of Paul's metaphor, Calvin also rejected certain individuals as the most likely spreaders of false teachings. As we saw above, most sixteenth-century medical authors tended to view visible cancer as a particularly female disease, manifesting itself through tumours in the breast or uterus. Insisting gangrene was Paul's vehicle, he therefore implicitly states that men rather than women were most likely to spread the false teachings - an assumption that makes a great deal of sense when we realize that the vast majority of sixteenth-century preachers and theologians were male. Contemporary understandings of temperament and the four humours also suggest that Calvin meant to emphasize men as the biological sex more likely to imperil the body of Christ with their false babbling. According to contemporary medical teachings, each person had a specific temperament, caused by his or her own unique balance of the qualities of hot, cold, wet, and dry. Though each individual had his or her own balance, sixteenth-century authors recognized commonalities due to biological sex: women tended to have temperaments in which the qualities of coldness and moistness predominated, whereas men's temperaments tended to be hot and dry. In addition to being associated with temperaments, these qualities were also connected to each of the four humours. Whereas black bile was associated with coldness and dryness, blood was thought to be hot and moist. Turning back to the supposed

55. Calvin, Commentarii in Epistolam Pauli ad Romanos, sig. Y2v and Commentarii in priorem espitolam Pauli ad Corinthios, sig. Bviv-Cir. A similar discussion appears in Calvin, Institutio Christianae religionis, sigs. Oir-v. 
causes of cancer and gangrene, cancer was most likely found in bodies where the qualities of cold and dry predominated-particularly in older female bodies. Gangrene, however, caused by an overabundance of corrupted blood, was to be found in bodies that were hot and moist-particularly male bodies. ${ }^{56}$ If viewed against the background of contemporary medical theories, Calvin's insistence that the disease of 2 Timothy 2:17 must be gangrene also suggested that men rather than women were most likely to spread those false teachings in a religious community, which could endanger the body of true believers.

This connection between hot and moist blood and gangrene also implied both the likely age of these men and the kind of personality they would possess, for two reasons: (1) an individual's age was thought to shape his or her temperament, and (2) this temperament was also thought to influence an individual's psychological and social characteristics, as well as his or her physical condition. ${ }^{57}$ Though Hippocrates and Galen had influentially articulated the connection between temperaments and personalities, Avicenna (d. $1037 \mathrm{CE}$ ), in his medical encyclopedia The Canon of Medicine, had developed the doctrine even further. The Canon of Medicine long served as an essential textbook for medical students in medieval and Renaissance Europe.$^{58}$ Avicenna, and the earlier work on which he drew, argued that qualities that determined an individual's temperament also made it so that one of the humours would predominate. Someone with hot and moist qualities, the person most likely to suffer from gangrene, would therefore be sanguine in personality because the humour of blood would predominate. Contemporaries taught that sanguine personalities tended to be extroverted and bold. It was also thought that men in the late youth and early adult periods of their lives tended to be more sanguine than other people in different life stages. ${ }^{59}$ Placing Calvin's insistence on gangrene as the disease of 2 Timothy 2:17 within the context of contemporary medical theories suggests

56. On the relationship between temperaments and humours in medieval and Renaissance medicine, see Nancy G. Siraisi, Medieval and Early Renaissance Medicine: An Introduction to Knowledge and Practice (Chicago: University of Chicago Press, 1990), 101-07. See also Brockliss and Jones, 110-12 and Lindemann, 88.

57. Siraisi, 103.

58. Brockliss and Jones, $85-119$.

59. Merry Wiesner-Hanks, Women and Gender in Early Modern Europe, 3rd ed. (Cambridge: Cambridge University Press, 2008), especially chapter 2, 41-81. 
that extroverted adolescent and early adult men were the most likely to spread false teachings in a religious community.

There is evidence within Calvin's commentary on 2 Timothy that he viewed these likely troublemakers as specifically male and sanguine in personality. In his second epistle to Timothy, Paul had mentioned two members of the Ephesian religious community, Hymenaeus and Philetus, as examples of people who were spreading false teachings within it. According to Calvin, these two men were plagues (pestes) in the community at Ephesus during Timothy's ministry. Their incorrect teachings about resurrection not only damned them, but threatened to destroy the body of Christ, had Timothy not rapidly dealt with their threat. ${ }^{60}$ Calvin's emphasis on this verse is on the spreading of their teachings, suggesting that the male Hymenaeus and Philetus were able to draw people to their false babblings in Ephesus perhaps due to their extroverted and bold personalities.

Calvin's discussion of how such people should be dealt with also resonated with contemporary discussions of how to treat gangrene. Much as sixteenth-century medical authors had argued, Calvin stressed that whenever the gangrene of false teachings arose in the religious community, it must be dealt with quickly. If people let the gangrene of false teachings fester, these teachings were liable to spread to such an extent that they threatened to cut off the Holy Spirit from the whole Church, just as gangrene that was not treated quickly would endanger the survival of the human body by cutting off that part from the vital spirit. ${ }^{61}$ Thus, the treatment for gangrene offered a model. According to contemporary medical authorities, if the accumulation of corrupted blood could not be cleared out of a person with gangrene, then surgical methodssuch as cutting out the gangrene and cauterizing the wound, or even amputating the limb in extreme cases-were necessary to save the body. Applying this medical treatment to Calvin's commentary implies that teachers of false doctrine should be excluded from the religious community or barred from the sacraments and excommunicated. If this treatment did not work, then the person must be executed for heresy-amputating him or her from the religious community. 
Geneva’s Ordonnances ecclésiastiques of 1541 as well as Calvin's 1543 Institutio Christianae religionis strongly suggest that he was in favour of such treatment for people whose teachings threatened to disturb entire religious communities. Calvin wrote the original draft of the Ordonnances ecclésiastiques, though the version the Genevan magistrates eventually accepted also contained numerous compromises, especially on the relative power of the civic government and the ministers of Geneva. The final section of the Ordonnances ecclésiastiques contains a passage about what to do with people who spread teachings contrary to received opinion. Assuming the person would not change his teachings under the pressure of admonition, the ministers were then to forbid the person from taking part in communion and to make the person known to the city's magistrates. ${ }^{62}$ Assuming the excising of the person from the religious community through the denial of communion did not work, Calvin's 1543 Institutio Christianae religionis suggests that these magistrates could execute them for heresy. Addressing the power of the magistrates in his chapter on political administration, he argues that they could shed blood and kill in order to protect the community. ${ }^{63}$

However, Calvin's insistence that the disease of 2 Timothy 2:17 must be gangrene was ultimately an optimistic claim about the survival of the body of the Church. As we saw above, contemporary medical professionals tended to consider cancer as quasi incurable. Gangrene, on the other hand, had two outcomes: it was curable, or it changed into a different disease and stopped being gangrene. By insisting on gangrene as the metaphorical disease of 2 Timothy 2:17, Calvin implicitly makes the argument that these false teachings would be stopped. True, just like gangrene, false teachings would arise in religious communities, especially from male extroverts. True, these clamourers would endanger other members of this community. However, since these teachings were a gangrene and not a cancer, members of the Church with God's aid would stop their spread in the end. God stopped the gangrene of false teachings from turning into the deadly disease of St. Anthony's fire. For Calvin, Paul's likening of these false teachings to gangrene rather than to cancer was an insistence on the continued survival of the Church despite the individual,

62. Les sources du droit du canton Genève, vol. 2: 1461-1550, ed. Émile Rivoire and Victor van Berchem (Arau: H.R. Sauerländer \& Cie, 1930), 388.

63. Calvin, Institutio Christianae religionis, sigs. rvr-v. 
infected members whom true believers might encounter in their contemporary religious communities.

\section{Conclusion: the gangrene of false teachings infects Geneva (1551-52)}

In 1551, just three years after Calvin's commentary on 2 Timothy appeared, the lecturing of Jérôme Bolsec (d. 1584), an ex-Carmelite friar and doctor, to the Geneva Company of Pastors on the subject of predestination set off events that led Calvin to adapt his exegesis of 2 Timothy 2:17 to a situation where false teachings seemed to threaten the religious community of Geneva. Bolsec had vehemently argued against the notion of double predestination to salvation and reprobation in his lecture and subsequent public statements in Geneva. In October 1551, the magistrates of Geneva had Bolsec arrested for his views. After seeking various opinions from Swiss Reformed theologians on predestination, they decided to exile Bolsec from the city. He took up residence in Berne and continued throughout the rest of his career to attack the doctrine of predestination as well as Calvin. ${ }^{64}$

Calvin responded to Bolsec's theological challenge in 1552 with a polemical tract entitled De aeterna Dei praedestinatione-a theological tract that the Geneva Company of Pastors also officially endorsed. ${ }^{65}$ In the dedicatory epistle to the magistrates of Geneva, he draws directly on notions contained in his distinctive translation of and commentary on 2 Timothy 2:17, as well as the wider medical and surgical background through which they had developed. Calvin argues here that Bolsec's lectures had caused false teachings to spread among the religious community of Geneva, creating tumult in the city. He also compares these teachings to gangrene that threatened the whole community. His concern was not for Bolsec, himself, whom Calvin seemed to have given up for damned at this point in 1552. Instead, he explains that he was worried that the infection would spread to other members of Geneva's religious community unless it was met quickly and with resolve. He offers De aeterna Dei

64. On this controversy, see the explanation and sources contained in Philip C. Holstrop, The Bolsec Controversy on Predestination, from 1551 to 1555, 2 vols. (Lewistown, NY: Edwin Mellen Press, 1993).

65. See the title page of Jean Calvin, De aeterna Dei praedestinatione, qua in salute alios ex hominibus esegit, alios suo exitio reliquit: item de providentia quae res humanas gubernat (Geneva: Jean Crispin, 1552). 
praedestinatione to such people as a remedy in order to protect them from the disease of Bolsec's false babblings. ${ }^{66}$

What has come to be known as the Bolsec Affair and Calvin's polemical response to Bolsec's teachings reveals the implications of Calvin's translation and commentary on 2 Timothy 2:17. Drawing on contemporary medical and surgical texts, as we saw in his 1548 commentary, Calvin and the Geneva magistrates developed a treatment to deal with the false teachings Bolsec spread. Having learned from Paul as well as contemporary physicians and surgeons that these teachings must be countered immediately or they would threaten the whole body of Christ, Calvin and the magistrates of Geneva he addressed with the text provided the members of their religious community with several solutions. The Geneva magistrates cut out the infected member from their midst when they exiled Bolsec from their city. Calvin, in writing De aeterna Dei praedestinatione, gave a further remedy in the form of an explanation of God's word for the true Church-those able to be cured. This tract was the antidote or unguent to the poison of Bolsec's profane babblings. In doing so, Calvin and the Geneva magistrates put his commentary on 2 Timothy 2:17 into action. But, according to Calvin, there was another lesson to take from this biblical verse. Since these teachings were like gangrene and not cancer, there was a good deal of hope that Bolsec's exile and Calvin's antidote would work. The religious community of Geneva and certainly those members of the body of Christ present within it would be saved.

If we read Calvin's translation and commentary on 2 Timothy 2:17 without knowing the medical and surgical texts that informed him, we risk missing a broader understanding of Calvin's exegetical method as well as the full connotations and implications of his exegesis of this verse. He certainly consulted other biblical translations and commentaries as he stated in his own work. Yet, it was the doctor, Benedict Textor, who treated Calvin and his wife and provided medical information, and the contemporary medical and surgical texts Calvin cited and discussed, that shaped both his commentary on the verse and his later interpretation and actions in the Bolsec Affair. As Parker has noted,

66. Calvin, De aeterna Dei praedestinatione, sigs. Aiir-Aiiir. The specific references to 2 Timothy 2:17 and the remedy his text provided occur on Aiiir. "Serpit instar gangrenae impietas, inquit Paulus, nisi obviam eatur. Ista autem, quam sub vestro nomine piis omnibus offerimus, defensio, tam erit ad curandos sanabiles, ut quidem speramus, validum efficaxque remedium, quam salubre antidotum sanis \& integris." 
this passage in Calvin's commentaries is remarkable, but the two hundred and fifty words that comprised it were not there just to explain the Greek word for gangrene, $\gamma \alpha \dot{\gamma} \gamma \gamma \rho a ı v a$. Instead, these two hundred and fifty words reflect some of Calvin's knowledge of medicine and reveal that consulting such texts was a part of his exegetical practice.

That Calvin consulted medical texts to support his exegesis also suggests that other sixteenth-century biblical commentators did likewise. Modern scholars have frequently and fruitfully compared the biblical commentaries of sixteenth-century authors to those of contemporaries and of predecessors. ${ }^{67}$ We are just beginning the work of examining these commentaries in conjunction with other fields of knowledge that flourished in the sixteenth century ${ }^{68}$ Calvin's commentary on 2 Timothy 2:17 suggests that modern scholars should continue to explore these other fields of sixteenth-century knowledge to understand these biblical commentaries fully, lest we begin to spread our own false teachings.

67. For Calvin, see David C. Steinmetz, Calvin in Context, 2nd ed. (Oxford: Oxford University Press, 2010).

68. On the relationship between Calvin's thought and sixteenth-century rhetoric, see Ford Lewis Battles, "God Was Accommodating Himself to Human Capacity," Interpretation 31 (1977): 19-38; Richard Stauffer, Die, la création de la Providence dans la prédication de Calvin (Berne, 1978); and Millet, Calvin et la dynamique de la parole: Etude de rhétorique réformée. On the relationship between Calvin's thought and the sixteenth-century study of nature, see Kaiser, Zachman, 122-25, and Susan E. Schreiner, The Theater of His Glory: Nature and the Natural Order in the Thought of John Calvin, Studies in Historical Theology 3 (Durham, NC: Labyrinth Press, 1991). On the relationship between Calvin's understanding of music and its relationship to contemporary musical theories, see Erin Lambert, "In Corde Iubilium: Music in Calvin's Institutes of the Christian Religion," Reformation and Renaissance Review 14.3 (2012): 269-87. See also Sachiko Kusukawa, The Transformation of Natural Philosophy: The Case of Philip Melanchthon (Cambridge: Cambridge University Press, 1995). 